\title{
COMPARISION OF REGENERATION OF SCOTS PINE PINUS SYLVESTRIS L. IN MYRTILLOSA AND HYLOCOMIOSA FOREST TYPES AFTER SHELTERWOOD CUTTINGS
}

\author{
Oto Rums ${ }^{1}$, *Inga Straupe ${ }^{1}$, Leonīds Zdors ${ }^{2}$ \\ ${ }^{1}$ Latvia University of Life Sciences and Technologies, Latvia \\ ${ }^{2}$ Latvian State Forest Reseach Institute 'Silava', Latvia \\ *Corresponding author’s email: inga.straupe@1lu.lv
}

\begin{abstract}
The aim of the study is to determine how successful the initial growth of naturally grown and planted pines is after performing the shelterwood cutting. The research includes tree count and height analysis in Myrtillosa and Hylocomiosa forest types with different regeneration methods in 2018. A total of 10 sites were arranged for the research, each site having 4 sample plots. All naturally regenerated and planted pine (2009, 2012 and 2013) heights were measured. Judging by the number of trees after shelterwood cutting, most sites should not be considered regenerated, additional planting or scarification of soil is required which can improve the efficiency of natural regeneration. In all the sites both in Myrtillosa and Hylocomiosa, after shelterwood cutting it was observed that the height of artificially regenerated trees is higher than the height of naturally regenerated trees, indicating the ability of planted pines to produce more rapid height increment in the first years of life, regardless of forest type. The basal area of the stand has a significant negative impact on the increment, and it indicates the need for the subsequent shelterwood cut to be performed. Although Hylocomiosa is a more fertile forest type than Myrtillosa, the height of the planted pine trees in Myrtillosa is higher than in Hylocomiosa, where, after shelterwood cutting, no sufficiently intensive agro-technical tending has been performed.
\end{abstract}

Key words: Pinus sylvestris, natural regeneration, artificial regeneration, Myrtillosa, Hylocomiosa.

\section{Introduction}

Shelterwood cutting is a type of final felling where a mature stand is felled in several turns. The advantages of this method include landscape attractiveness and continuous tree canopy closure, reduced impact of biotic and abiotic disturbances as well as reduced competition of herbaceous plants. The forest stand is expected to regenerate in a natural way in the shelterwood cutting sites. In some cases, trees are also planted. In order for natural regeneration to fully occur in shelterwood cuttings, at the beginning of their life young trees need to be shielded by old trees, and this shield can serve as a seed base and protect them from frost and other hazards (Matthews, 1991). The retained trees also preserve the ecological legacies and help maintain the existing vegetation composition of the forest stand (Nyland, 2016). With this type of felling, the soil is better protected from drying out, which is facilitated by open felling areas (Matthews, 1991). A successful shelterwood cutting site regeneration involves the practice of naturally regenerated trees being supplemented with planted ones, thus ensuring an even and complete regeneration with the desirable tree species (Matthews, 1991). By cutting down a part of mature trees in shelterwood sites, the remaining trees are provided with favorable growth conditions, thus making it possible to obtain high-quality and large-dimension commercial wood in the forest. The old generation of Scots pine needs to be preserved until the new generation is fully developed, and when this has happened, it is advisable to cut down the mature trees or significantly reduce their number in the forest stand (Valkonen, 2014). In the research on group shelterwood cuttings in Latvia, the positive increment in the trunk volume is attained two years after felling, whereas the positive effect of the openings is observed in a $7 \mathrm{~m}$ zone around them. Accordingly, the volume increments in the trees which are farther than $7 \mathrm{~m}$ away from the openings are several times smaller (Zdors et al., 2017). The average tree height increment in shelterwood cuttings at the distance of 10 $\mathrm{m}$ from the stand's mature trees is similar to the height increment of planted Scots pine trees in clearcut areas (Strand et al., 2006). The incremental growth of the trees remaining in continuous shelterwood sites depends on the basal area of the thinned stand, where larger increments are expected at a smaller basal area of the stand (Donis, 2015).

Studies have shown that the light requirements of young plants increase with age. Under shady growing conditions, the diameter of Scots pine is expected to decrease, which means that the pines of the same height will be thinner in shaded areas, whereas larger diameter trees will be able to grow in areas where more light is available (Gaudio et al., 2011). Consequently, as light conditions increase, the diameter of the pine root collar also increases, indicating a better root system development (Zdors \& Donis, 2017).

In the planted areas of shelterwood cuttings, the height increments of the Scots pine trees planted after the first cut decreased compared with the growth demonstrated three years after the cut. This is explained by the increasing demands for resources facilitating growth, such as - nutrients, water and light as seedlings develop. In practice, the adverse effects of competition of tree stand can be avoided by timely 
planned next shelterwood cut technique or by even more extensive thinning of mature trees in the forest stand (Nilsson et al., 2006). Thinning of the tree stand in advance in shelterwood cutting promotes the growth of herbaceous vegetation due to the available amount of light, which makes it difficult for pine seeds to reach the soil. As light intensity increases, soil temperature also rises, which increases the trees' competition for water resources in the summer months (Barbeito et al., 2011). Competition between planted Scots pine is observed after 4-6 years. As they reach this age, the tree crowns gradually form the canopy closure and the roots of the trees also begin to compete with each other, which determines the future development of the tree stand (Jansons, 2008).

The aim of the study is to determine how successful the initial growth of naturally grown and planted pines is after performing the shelterwood cutting.

\section{Materials and Methods}

A total of 10 sites were arranged for the research, each site having 4 sample plots. The forest types were Myrtillosa and Hylocomiosa. Four sites are located in the western part of Latvia, on the southwestern coast of the Gulf of Riga in the lowland plain, while six sites are located in the eastern part of Latvia, in the North Vidzeme. In each site four $500 \mathrm{~m}^{2}$ circular plots were arranged (Figure 1). The distance between the centres of the plots was at least $30 \mathrm{~m}$, and the centres were placed at least $30 \mathrm{~m}$ from the edge of the stand. In the sample plot (radius $12.62 \mathrm{~m}$; area $500 \mathrm{~m}^{2}$ ) all naturally regenerated and planted pine (2009, 2012 and 2013) with a diameter at breast height of more than $14.0 \mathrm{~cm}$ were measured. Trees with a diameter of more than $6.0 \mathrm{~cm}$ but not exceeding $14.0 \mathrm{~cm}$ were measured within a radius of $5.64 \mathrm{~m}$ from the sample plot centre (in the area of $100 \mathrm{~m}^{2}$ ). Trees with a diameter of $2.1-$ $6.0 \mathrm{~cm}$ were measured within a radius of $3.99 \mathrm{~m}$ from the centre of the sample plot (area $50 \mathrm{~m}^{2}$ ) (Figure 2). For each tree, its distance from the centre, its species, layer, current status (growing, snag or log) and diameter were recorded. The logs were measured at a distance of $1.3 \mathrm{~m}$ from the root collar. In each sample plot at least three tree heights were measured, so that the total number of trees measured would be at least 12 trees per site. For the assessment of plantings and natural regeneration, circular plots of $25 \mathrm{~m}^{2}$ were established in the sample plots. The centres of these plots were located in the centres of the large circular sample plots and at a distance of $6 \mathrm{~m}$ from them in the $\mathrm{N}$ and $\mathrm{S}$ directions. All naturally regenerated and planted pine heights were measured. Four of the shelterwood sites were cut in 2013, two in 2012, and four other sites were cut in 2009. When analysing the tree heights, no significant differences were found in the tree heights between the sites felled in 2012 and 2013; therefore, both data sets were analysed together. In the sites, the parameters of the stand were calculated for each sample plot - average diameter, average height, basal area, tree volume, standing volume, average root collar diameter of young trees, and average annual increments, using generally accepted formula in forest inventory parameters (Skudra \& Dreimanis, 1993; Liepa, 1996; Sharma \& Breidenbach, 2015). In the regeneration assessment, the height analysis of the new generation of trees was performed using the data processing programme SPSS, applying the tool Univariate Analysis of Variance.

\section{Results and Discussion}

The researched forest stands have been regenerated in different ways: five of them naturally and five

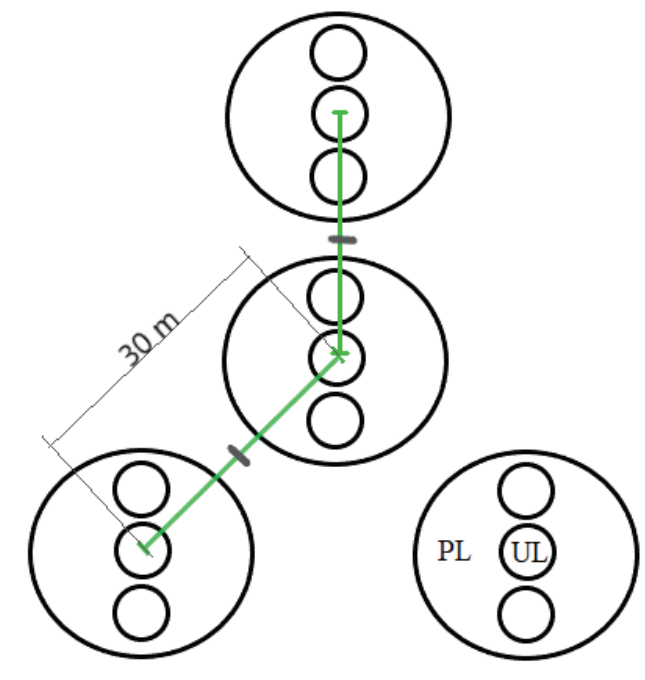

Figure 1. The distribution of sample plots in the object. Abbreviations: PL - sample plot, UL - plot.

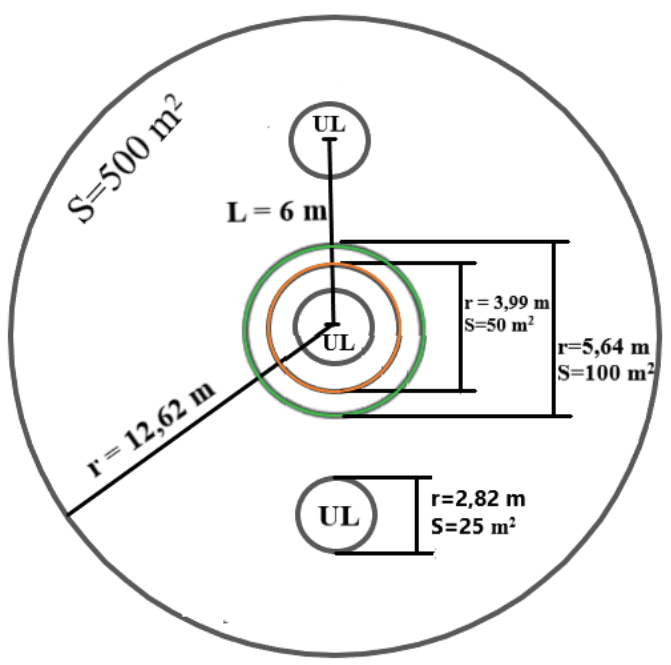

Figure 2. The size of sample plots and plots.

Abbreviations: $\mathrm{UL}$ - plots, $\mathrm{S}$ - area, $\mathrm{r}$ - radius, $\mathrm{L}$ - distance. 
The number of trees in objects, where Scots pine was planted

\begin{tabular}{|c|c|c|c|c|}
\hline $\begin{array}{c}\text { Number of object, } \\
\text { forest type, } \\
\text { year of felling }\end{array}$ & $\mathrm{P}_{\mathrm{pl}}, \mathrm{N}^{*} \mathrm{ha}^{-1}$ & $\mathrm{P}_{\text {nat }}, \mathrm{N}^{*} \mathrm{ha}^{-1}$ & $\mathrm{P}_{\text {nat }}+\mathrm{P}_{\mathrm{pl}}, \mathrm{N}^{*} \mathrm{ha}^{-1}$ & $\begin{array}{c}\text { Uniformity of } \\
\text { regeneration (success of } \\
\text { regeneration), \% }\end{array}$ \\
\hline $1 \mathrm{H}, 2013$ & $1266.7 \pm 230.1$ & $3633.3 \pm 861.9$ & $4900 \pm 1008$ & 83.3 \\
\hline $2 \mathrm{H}, 2013$ & $933.3 \pm 242.9$ & $4400 \pm 926.4$ & $5333.3 \pm 1044.9$ & 58.3 \\
\hline $3 \mathrm{M}, 2013$ & $1133.3 \pm 189.6$ & $13866.7 \pm 2099$ & $15000 \pm 2135.1$ & 100 \\
\hline $4 \mathrm{M}, 2009$ & $1000 \pm 159.5$ & $2300 \pm 587$ & $3300 \pm 611.3$ & 41.6 \\
\hline $5 \mathrm{M}, 2009$ & $1000 \pm 187.5$ & $1233.3 \pm 301.3$ & $2233.3 \pm 436.1$ & 41.6 \\
\hline
\end{tabular}

Abbreviations: $\mathrm{P}_{\mathrm{pl}}$ - planted trees; $\mathrm{P}_{\text {nat }}$ - naturally regenerated trees; $\mathrm{N}$ - number; $\mathrm{H}$ - Hylocomiosa; $\mathrm{M}-$ Myrtillosa.

The number of trees in objects where natural regeneration was carried out

Table 2

\begin{tabular}{|c|c|c|}
\hline $\begin{array}{c}\text { The number of object, forest type, } \\
\text { year of felling }\end{array}$ & $\mathrm{P}_{\text {nat }}, \mathrm{N}^{*} \mathrm{ha}^{-1}$ & $\begin{array}{c}\text { Uniformity of regeneration } \\
\text { (success of regeneration), } \%\end{array}$ \\
\hline $6 \mathrm{H}, 2013$ & $5600 \pm 1231.9$ & 66.67 \\
\hline $7 \mathrm{M}, 2012$ & $7166.7 \pm 1378.1$ & 75 \\
\hline $8 \mathrm{H}, 2012$ & $3566.7 \pm 945.1$ & 53.3 \\
\hline $9 \mathrm{M}, 2009$ & $3700 \pm 694.8$ & 100 \\
\hline $10 \mathrm{M}, 2009$ & $5666.7 \pm 671.2$ & 50 \\
\hline
\end{tabular}

Abbreviations: $\mathrm{P}_{\text {nat }}$ - naturally regenerated trees; $\mathrm{N}$ - number; $\mathrm{H}-$ Hylocomiosa $; \mathrm{M}-$ Myrtillosa.

artificially. In all stands the dominant tree species is Scots pine, five stands are composed only of Scots pine trees. The rest of the sites have the admixture of other tree species. The number of old-generation trees in the studied sites ranges from 65 to 235 trees per hectare, the average tree height in the sites is from $24.6 \mathrm{~m}$ to $34 \mathrm{~m}$ and the average DBH - from $32.4 \mathrm{~cm}$ to $59.6 \mathrm{~cm}$.

Analysis of the number of trees in the research sites. According to Latvian legislation, the minimum required number of the established trees which are to be regenerated with Scots pines is 3000 trees per hectare. The number of trees in the researched shelterwood sites where planting was carried out is shown in Table 1.

The number of trees according to their origin (natural or artificial) is calculated as an average parameter in all 12 plots in the site. The number of planted pines in all the research sites is not sufficient to consider the area as regenerated. Pine regeneration naturally has been much more successful, reaching up to 13866 trees per hectare in one site. By combining the number of planted and naturally regenerated pines, the average number of young trees in four of the five sites is sufficient, and the minimum required number of the plants that have established in these sites has been exceeded.

An important indicator for the evaluation of stand regeneration is the uniformity of regeneration (\%) which characterizes the success of the regeneration in the site as a whole. It is calculated by determining the ratio between the number of accounting areas in the site where the total amount of artificially and naturally regenerated trees reaches at least the minimum number of trees required, which is 3000 trees per hectare, and the total number of accounting areas which equals 12 . When calculating the uniformity of the regeneration, it can be concluded that only two of the five planted sites have achieved the necessary criteria for a stand to be considered regenerated - regeneration has been uniformed over the area of $83.3 \%$ and $100 \%$ respectively. The sites where natural regeneration was planned after shelterwood cutting are shown in Table 2.

The average number of trees in all sites was more than the minimum number of trees required per hectare, but also in these sites the regeneration was not uniformed throughout the stand, with the highest average number of trees by the accounting areas being $7166.7 \pm 1378.1$ trees and the lowest average amount in the site $3566.7 \pm 945.1$ trees per hectare. Only one site is considered to be uniformly regenerated. Analysing the number of trees in sites, it can be concluded that, irrespective of the type of regeneration, most sites after shelterwood cutting are not to be considered regenerated. It is anticipated that when subsequent cuts are carried out, additional space for natural regeneration will be provided. 


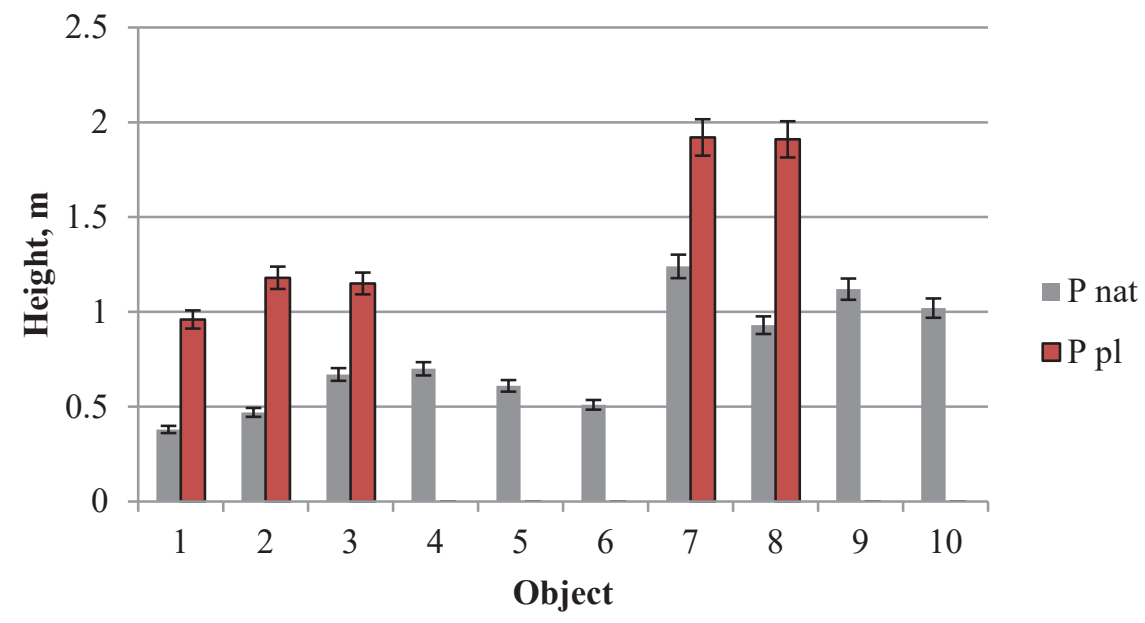

Figure 3. The average height of trees for both naturally regenerated and planted trees.

Mean values are shown \pm SE. Abbreviations: P nat - naturally regenerated pines, $\mathrm{P} \mathrm{pl}-$ planted pines.

Tree height analysis in the research sites. The tree height analysis shows what height the new generation trees have reached in the research sites after shelterwood cutting in Myrtillosa and Hylocomiosa forest types with different regeneration methods. The average height of trees for both naturally regenerated and planted trees is shown in Fig. 3.

In the six sites (felled in 2012 and 2013), tree heights were lower than in other four sites (felled in 2009). It can be seen that in the sites where Scots pines were planted, they were higher than the naturally regenerated pines growing in the same site. The difference in height is due to the fact that selected saplings are more productive than naturally regenerated ones, they have higher genetic quality, and both containerised and bare root plants have welldeveloped and wide root system as well as species proportional roots and shoots, which allow the tree to fully use nutrient and water resources.

The basal area of the remaining stand has a significant influence on the height of seedlings. When the basal area of the stand is larger, the height of the plants decreases. The negative impact of the increasing basal area on the tree height can be explained by the fact that in the meantime not only the new generation has taken root and grown, but also the shelter stand has increased. For the remaining trees of the stand after shelterwood cutting, immediate root growth can be expected, but the increment of the trunk volume is not observed immediately after cutting, and this period lasts from 2 to 4 years (Jakobsson, 2005). After continuous shelterwood cuttings carried out in Latvia, in most cases during the first two years after felling there has been an additional increment of the remaining stand, which is a part of the increment of the stand resulting from the impact. In its turn, the maximum of the reduced additional growth in Vacciniosa is reached in 5-7 years, while in Myrtillosa and Hylocomiosa the maximum is reached in 3-4 years (Liepa, 1996; Zdors, 2015).

After shelterwood cutting, the feeding conditions of the remaining trees improve, the competition between the trees decreases and the light conditions improve, consequently the increase in the growth of the remaining trees in the stand can be expected. Considering that the research has shown the reduced additional maximum growth increment in Myrtillosa at the age of 3-4 years after performing shelterwood cutting, it is reasonable to assume that in the sites 9 years after felling, the maximum of the reduced additional increment has already been reached and the increment of the mature trees has significantly increased.

The research in Latvia has proved that the competition between young trees begins to appear at the age of 4-6. When this age has been reached, the tree crowns gradually close and the roots of the trees also begin to compete with each other (Jansons, 2008). Analysis of variance shows a significant negative effect of basal area on the height of new generation trees $(p=0.000)$. This is due to the fact that 9 years after cutting, competition between the younger generation trees begins to increase, while the remaining trees in the stand have filled the growing space and start to negatively affect the growth of the new generation pine trees by reducing the amount of light in the felled areas. Timely performed subsequent cut improves the development of both planted and naturally regenerated plants (Nilsson et al., 2006). Since the height of the trees in the sites 9 years after cutting shows a decrease at a larger basal area, it can be concluded that there is a need for the subsequent shelterwood cut in these stands. 


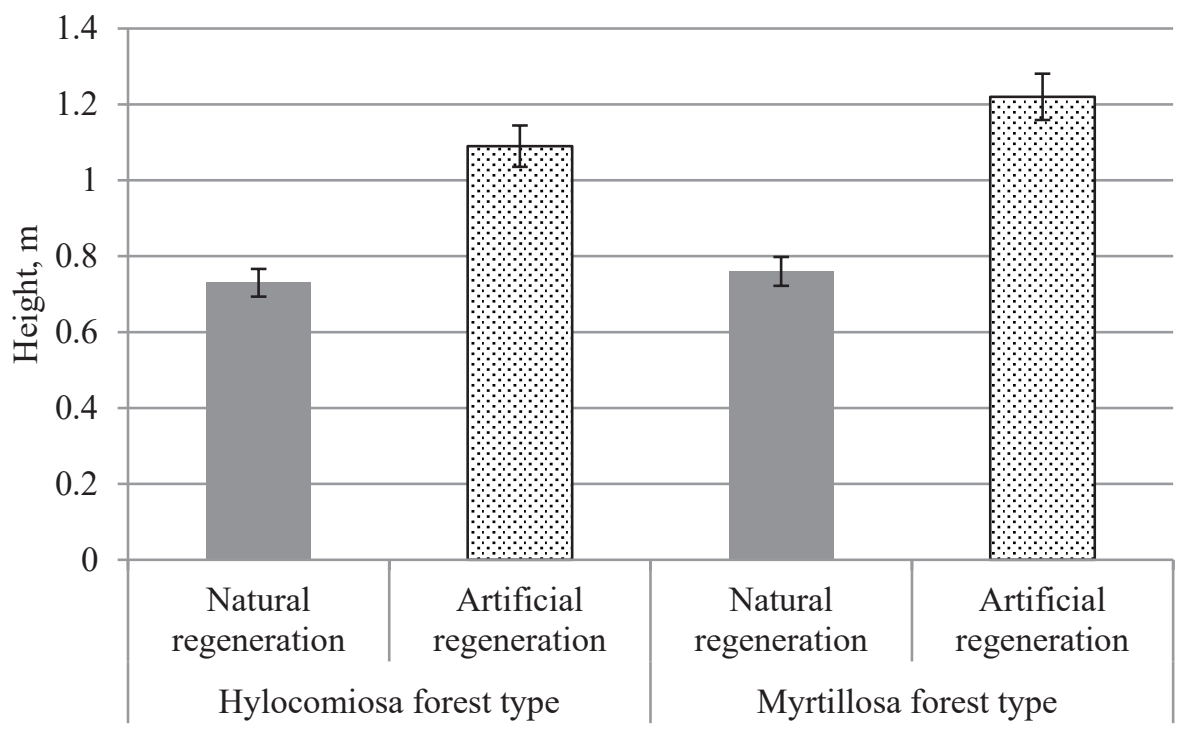

Figure 4. The height of trees by types of natural and artificial regeneration in the felling sites of the year 2013. Mean values are shown \pm SE.

The differences in the height of new generation trees by types of regeneration in the felling sites of the year 2013 can be seen in Fig. 4.

Variance analysis in both Myrtillosa and Hylocomiosa with $95 \%$ probability indicates that significant height differences are caused by the choice of the regeneration method $(p=0.000)$, while the basal area of the remaining stand is not significant $(\mathrm{p}=0.340)$. In both Myrtillosa and Hylocomiosa, like previously - in the shelterwood cuttings of 2009, the height of artificially regenerated trees was observed to be higher than that of naturally regenerated trees, indicating the ability of planted trees to produce more rapid height increment in the first years of life after planting, irrespective of forest type. The height of naturally regenerated trees in Hylocomiosa is insignificantly lower than that of naturally regenerated trees in Myrtillosa. Although Hylocomiosa is a more fertile forest type than Myrtillosa, the height of planted pine trees in the latter is not significantly lower than in Hylocomiosa forest type. As it has been found, the reduced additional increment in Myrtillosa and Hylocomiosa started within 3-4 years after shelterwood cutting. In the cuttings of 2013, no significant impact of basal area on plant height was observed, thus the light conditions in the felled areas were sufficient and did not adversely affect pine growth. Under Hylocomiosa forest type, light conditions improve after cutting, and on fertile soils an increased shading by herbaceous plants is forming. The frequency of weeding depends on this shading and should be planned accordingly: to improve the growing conditions of the plants, it is necessary to schedule the weeding at least once a year, but if the shading of herbaceous plants is large, tending should be performed twice a year. If weeding is not performed, much of the available nutrients and water are consumed by herbaceous plants, thus impeding the growth of young trees (Skudra \& Dreimanis, 1993). As the height of the trees in Hylocomiosa is lower than in Myrtillosa, it is reasonable to assume that after shelterwood cutting there has not been sufficient weeding.

\section{Conclusions}

1. Estimated by the number of trees after shelterwood cutting, most sites should not be considered successfully regenerated; additional planting or scarification of soil is required which can improve the natural regeneration.

2. In all the sites both in Myrtillosa and Hylocomiosa, after shelterwood cutting it was observed that the height of artificially regenerated trees is significantly higher than the height of naturally regenerated trees, indicating the ability of planted pines to produce more rapid height increment in the first years of life, regardless of forest type.

3. The basal area of the remaining stand has a significant negative impact on the height increment of naturally regenerated and planted pines, and it indicates the need for the subsequent shelterwood cut to be performed.

4. Although Hylocomiosa is a more fertile forest type than Myrtillosa, the height of the planted pine trees in Myrtillosa is higher than in Hylocomiosa, where, after shelterwood cutting, no sufficiently intensive weeding has been performed in both forest types. 


\section{Acknowledgements}

The study was carried out within the framework of the research 'Improvement of Growth Process Models' of Latvian State Forest Research Institute
'Silava' and was supported by the grant of project of Latvia University of Life Sciences and Technologies 'Implementation of LLU research programme'.

\section{References}

Barbeito, I., Lemay, V., Calama, R., \& Cañellas, I. (2011). Shelterwood systems within a multiscale framework Regeneration of Mediterranean Pinus sylvestris under two alternative shelterwood systems within a multiscale framework. Canadian Journal of Forest Research, 41(2), 341-351. DOI: 10.1139/X10-214.

Strand, M., Löfvenius, M.O., Bergsten, U., Lundmark, T., \& Rosvall, O. (2006). Height growth of planted conifer seedlings in relation to solar radiation and position in Scots pine shelterwood. Forest Ecology and Management, 224 (3), 258-265. DOI: 10.1016/j.foreco.2005.12.038.

Donis, J. (2015). Mežaudžu augšanas gaitas un pieauguma noteikšana, izmantojot pārmērītos meža statistiskās inventarizācijas datus (Determination of growth rate and growth of forest stands using remeasured forest statistical inventory data). Salaspils: Latvijas Valsts Mežzinātnes institūts 'Silava'. (in Latvian).

Gaudio, N., Balandier, P., Perret, S., \& Ginisty, C. (2011). Growth of understorey Scots pine Pinus sylvestris saplings in response to light in mixed temperate forest. Forestry: An International Journal of Forest Research, 84 (2), 187-195. DOI: 10.1093/forestry/cpr005.

Jakobsson, R. (2005). Growth of retained Scots pines and their influence on the new stand. Doctoral thesis. Umeå, Swedish University of Agricultural Sciences: Acta Universitatis Agriculturae Sueciae 34.

Jansons, Ā., \& Džeriņš, A. (2008). Scots pine (Pinus sylvestris L.) stand phenotypic parameters depending on its juvenile stand density. LLU Raksti, 20 (315), 66-75.

Liepa, I. (1996). Pieauguma mācība (The study of increment). Jelgava: LLU. (in Latvian).

Matthews, J.D. (1991). Silvicultural Systems. Oxford: Clarendon Press.

Nilsson, U., Örlander, G., \& Karlsson, M. (2006). Establishing mixed forests in Sweden by combining planting and natural regeneration - Effects of shelterwoods and scarification. Forest Ecology and Management. 237, 301-311. DOI: 10.1016/j.foreco.2006.09.053.

Nyland, R.D. (2016). Silvicultural concepts and applications. $3^{\text {rd }}$ edition. USA: Waveland Press.

Sharma, R.P., \& Breidenbach, J. (2015). Modeling height-diameter relationships for Norway spruce, Scots pine and downy birch using Norwegian national forest inventory data. Forest Science and Technology, 11(1), 44-53. DOI: 10.1080/21580103.2014.957354.

Skudra, P., \& Dreimanis, A. (1993). Mežsaimniecības pamati (The base of forestry). Rīga: Zvaigzne. (in Latvian).

Valkonen, S. (2000). Effect of retained Scots pine trees on regeneration, growth, form and yield of forest stands effect of retained scots pine trees. Investigación agraria. Sistemas y recursos forestales. 9 (1), 121-146. DOI: $10.5424 / 680$.

Zdors, L. (2015). Kokaudzes struktūras un apsaimniekošanas režīmu ietekme uz parastās priedes (Pinus sylvestris L.) atjaunošanos vienlaidus un grupu pakāpeniskajās cirtēs (Impact of tree stand structure and management regimes on the regeneration of continuous pine (Pinus sylvestris L.) in continuous and group fellings). Jelgava: LLU. (in Latvian).

Zdors, L., \& Donis, J. (2017). Evaluating the edge effect on the initial survival and growth of Scots pine and Norway spruce after planting in different size gaps in Shelterwood. Baltic Forestry, 23(2), 534-543.

Zdors, L., Šņepsts, G., \& Donis, J. (2017). Stem volume increment after group shelterwood cutting in Scots Pine stands in Myrtillosa forest type. Baltic Forestry, 23 (2), 463-470. 